\title{
REGISTRATION OF PROPERTY RIGHTS WITH SPECIAL EMPHASIS ON THE RIGHT OF OWNERSHIP AND THE RIGHT OF REAL SERVITUDE OVER IMMOVABLE PROPERTY ACCORDING TO LEGISLATION AND LEGAL PRACTICE
}

\author{
Kastriote Vlahna ${ }^{1}$ \\ Hajredin Kuçi ${ }^{2}$
}

\begin{abstract}
Property rights, both property rights and servitude rights and other property rights, can be acquired but those rights must first be created. This created right comes from a legal title that can be a valid legal work (contract, will), from a state decision (court decision or administrative decision) as well as definition by law. In all these cases, the right of servitude is created, as well as the right of ownership, which means that with the legal title (iustus titulus) it is declared only that the right has been created, but it has not been acquired (constituted) yet. In order to acquire the property right, not only the legal title (iustut titulus) is enough, but also the registration (modus purchase) of the right must be done. So that right must be recorded in the public books of real estate. But not all legislations of countries gain the right of servitude and ownership by registration, because unlike the legislation of Kosovo, the legislations of other countries allow the right of servitude as well as the right of ownership and the rights of other real estate, can be created only with a valid legal title, while the legal provisions are not defined for the registration of the created right. Thus, in the content of this paper, the way of gaining property rights over immovable property is presented. And specifically by clarifying the progress of the procedure of registration of the right in the book of real estate, based on the legislation and legal practice of the Cadastral status.
\end{abstract}

Keywords: Keywords: property rights, Servitude right, creation, and registration of rights;

\section{Entry}

Well-defined and enforceable property rights are a prerequisite for the functioning of a market economy. As long as these rights are weak, a market economy cannot serve effectively and economic progress is severely hampered. The Albanian experience is not unique in this field. After the fall of communism, many Central and Eastern European countries faced similar challenges, including the former German Democratic Republic. The German experience has shown some elements: From a legal point of view, it seemed logical to return the confiscated properties to the former owners and a large majority voted in favor of their return. At that time, the possibility of compensation was associated with a heavy financial burden. In practice, deciding on the rightful owner of a property proved to be extremely difficult in many cases. The industrial structure of East Germany had completely changed. It was difficult to distinguish between owning a company and real estate. Land registers were neglected by the GDR authorities and were incomplete, and in most cases the former owners were no longer living, so property issues were also subject to unresolved inheritance issues. Not only property rights but also other property rights such as servitude rights, pledge rights, encumbrances and construction rights. As a result, there were many applicants for a large number of properties. As long as property rights were not clearly defined, it was difficult to attract potential investors, enterprises lost many investment opportunities and had difficulty financing their business.

\section{Registration of property rights over immovable property according to the legislation in Kosovo}

The Register of Immovable Property Rights (hereinafter: the Register), has been established as a mechanism that recognizes and implements the validity of immovable property rights in Kosovo in accordance with applicable laws. ${ }^{3}$ Kosovo Cadastral Agency (hereinafter: "ACA") is authorized to make the general administration of the Register in accordance with the provisions of applicable laws. Municipal Cadastral Offices (hereinafter: "MCO") register the rights

\footnotetext{
${ }^{1}$ PhD.C. Kastriote Vlahna - Doctoral student at the University "Hasan Prishtina" Pristina, Kosovo, Department of Civil Law, and I am employed as a full time assistant in the field of Civil Justice, Faculty of Law, University of Prizren "Ukshin Hoti" Prizren, Republic of Kosovo. My contact email address: kastriote.vlahna@uniprizren.com.

${ }^{2}$ Prof. Dr. Hajredin Kuçi - Regular professor in the field of law of Private Law, Faculty of Law, University of Pristina 'Hasan Pristina', Pristina, Republic of Kosovo, hajredin.kuci@uni-pr.edu.

${ }^{3}$ Law no. 2002/5, On the Establishment of the Register of Immovable Property Rights, Article 1, paragraph 1.1.
} 
ISSN 2661-2666 (Online) International Scientific Journal Monte (ISJM) DOI: $10.33807 /$ monte.20211895

Volume 4, (No).2 (2021): April

over the immovable property and that in the Immovable Property Register, under the authority of the KCA and in accordance with the provisions of this law and administrative instructions issued by the KCA. ${ }^{4}$

For the registration of property rights, such as the right of servitude over immovable property, in order to acquire that right, a written request must be made to the MCO in which the immovable property is located. The MCO will confirm the time and date of receipt of the registration request.

The application for registration can be submitted by

- the owner of the property or by a person authorized by the owner;

- the person who has the right to claim ownership of the property through the transaction for it

- real estate and with the prior written consent of the owner.

The applicant seeking to register the immovable property right must attach the application documentation to support the immovable property right. The MCO will register the immovable rights only on the basis of the listed legal documents

Requests for registration of immovable property rights are submitted in writing to the MCO in the territory where the immovable property is located. The MCO will confirm the date and time of receipt of the registration request. The applicant requesting the registration of immovable property rights must attach the relevant documentation to the application to support the immovable property right as required by applicable law. ${ }^{6}$ The MCO will review the submitted documentation and if this documentation is not sufficient under applicable law, the MCO sets a deadline for the Applicant to complete the documentation. ${ }^{7}$ The MCO refuses to register if the submitted documentation is not sufficient to prove that the applicant is the holder of:

(i) the right to immovable property required for registration;

(ii) if the request and supporting documents contain obvious irregularities;

(iii) whether the validity of the claim or any of the supporting documents is in question; AND

(iv) if the documentation is incomplete and does not provide a basis for registration. ${ }^{8}$

After review and evaluation, the MCO will make a written decision and thus register the immovable property right, within fifteen (15) days from the date of receipt of the application for registration and will notify the applicant. The registration takes effect when the decision to register the MCO is entered in the Register.

\section{1. General description of the process}

The land cadastre contains textual and graphic data on cadastral parcels, area, culture, solvency and their class and data on buildings, parts of buildings, conductors and underground facilities in Kosovo. ${ }^{9}$

Registration in the cadastre or re-regulation of the cadastral border requires cadastral survey by a staff certified by the $\mathrm{MCO},{ }^{10}$ a licensed company or a surveyor. ${ }^{11}$ In the first case, all registration and measurement is done by the $\mathrm{MCO}$ in which the cadastral zone is located. In the second case, the company acts as an agent of the applicant who makes all the measurements and collects all the necessary documents for registration. The company submits the data to the MCO, which performs cadastral work and registers.

\section{2. Request for cadastral survey}

In case the application is submitted through a licensed company or through a surveyor, the applicant must submit to them:

- authorization from a lawyer who authorizes the company or surveyor to represent or

- to act on his / her behalf during the registration process; all necessary documents for property

transfer and registration.

The request submitted to the MCO must also contain a request for registration in the cadastre.

${ }^{4}$ Ibid. Article 1. paragraph 1.2.

${ }^{5}$ Law no. 2002/5, On the Establishment of the Register of Immovable Property Rights, Article 3. Paragraph 1.

${ }^{6}$ Ibid. Article 3, Paragraph 2;

${ }^{7}$ Ibid. Article 3, Paragraph 3;

${ }^{8}$ Ibid. Article 3, Paragraph 3;

${ }^{9}$ Ibid. Article 3, paragraph 5;

${ }^{10}$ Law no. 2002/5, On the Establishment of the Register of Immovable Property Rights, Article 3. Paragraph 5.

${ }^{11}$ Ibid. 
ISSN 2661-2666 (Online) International Scientific Journal Monte (ISJM) DOI: $10.33807 /$ monte.20211895

Volume 4, (No).2 (2021): April

Official procedure applied by the Immovable Property Registration Offices. Document files required for each property category. The initial registration of real estate is done by preparing real estate cards and documenting the boundaries of these properties in the Registration Indicative Map. The property rights as well as the boundaries of each immovable property are verified by submitting the following documents to the Immovable Property Registration Office. In each case, the legislation is given where all those citizens who want to carry out an initial registration of the real estate they own should be based for further procedures. For all those who want to register the real estate that has received this property thanks to Law no. 7501 need as a document the deed of acquisition of land in use or ownership. ${ }^{12}$

\section{3. Preparations by the Surveyor}

For every application submitted by citizens for registration in the cadastre, adjustment of cadastral boundaries, marking, etc., the surveyor is obliged to: ${ }^{13}$

- check the surface differences between the graphic and textual database;

- check vector data against old cadastral plans (raster);

- analyze cadastral plans by introducing first, second and order checkpoints

- third and other points with known precise coordinates;

- compare the cadastral map with the original terrain measurements

- check the cadastral map against other relevant maps.

After completing the above analysis and concluding that there are discrepancies, the MCO should inform the KCA in writing and submit all documents produced by this study.

\section{4. Preparation of data for the surveyor}

On behalf of the applicants, the surveyor requests from the MCO all graphs of information and texts in use for a cadastral personality / ability.

Text data is retrieved and exported by KCLIS-T. For this rule, the registrar processing a Case for a system, and selecting "Data Service of the Selected Cadastral Unit for Surveyors" from the drop-down menu - Case Type $.{ }^{14} \mathrm{He} / \mathrm{she}$ then enters a Case Placement page, where the case is on that to-do list, and exports the CSV file with the text data. ${ }^{15}$

Graphic data are exported by KCLIS-HK. For this reason, the official and the processor enters the Current Status presentation and generates the Cadastral Unit Report, if the Map of Adjacent Parcels in PDF format is required. In presenting the current state, he / she uses the polygon selection to export border points and lines (or other necessary features) in CSV, GML, form, DWG or ITF format.

\section{5. Registration request}

The request for registration must be made in writing to the MCO in which the cadastral unit is located. The MCO must confirm the time and date of registration of the receipt of the request.

The applicant must attach to the request cadastral measurements for registration in the cadastre, as well as other relevant documents to support the request, according to the provisions of applicable law included in Chapter 3 of this publication. The request must be submitted within 60 days of cadastral measurements. ${ }^{16}$

\section{5. 1. Request review}

The MCO should review the submitted documents. If the request or cadastral measurements do not contain all the data required by law and this administrative instruction, the MCO will set a deadline for the applicant to rectify this issue. ${ }^{17}$ The

\footnotetext{
${ }^{12}$ See: Law No. 2003/25 on Kosovo Cadastre; Article 6, paragraph 1;

${ }^{13}$ Municipal Cadastral Office. Municipal body responsible for registering data in the Cadastre. MCOs may also be responsible for cadastral procedures and measurements. MCOs carry out their cadastral activities under the supervision of the KCA.

${ }^{14}$ Hereinafter "licensed MCO staff, licensed company or surveyor" is called "surveyors".

${ }^{15}$ See: https://www.shqiperia.com/ Mortgage-documents-needed-for-initial-registration-of-property, p, 7431;

${ }^{16}$ See: Law no. 04 / -L-013 on Cadastre, Article 13, Paragraph 3.

${ }^{17}$ Ibid. Article 13, Paragraph 4.
} 
ISSN 2661-2666 (Online) International Scientific Journal Monte (ISJM) DOI: $10.33807 /$ monte.20211895

Volume 4, (No).2 (2021): April

MCO has the duty to notify the Applicant in writing about the deficiencies found. If the Applicant does not complete the required documentation within the deadline, the $\mathrm{MCO}$ will refuse to register the property unit.

The MCO will refuse registration if:

- the submitted documentation is not sufficient to prove that the applicant i the claimant is the holder of the right to that immovable property.

- The request and supporting documents contain obvious irregularities.

- The validity of the request or any of the supporting documents is debatable.

- If the documentation is deficient and there can be no basis for registration.

The MCO must make a decision and make the registration within 3 days from the date of the request. ${ }^{18}$ The applicant must be notified immediately upon completion. Registration is effective upon entry of the $\mathrm{MCO}$ decision into the register.

\section{5. 2. Review}

Within 30 days of receiving written notice from the MCO on the refusal to register the immovable property right, the Applicant may request the MCO to reconsider the decision. ${ }^{19}$ The MCO will confirm the time and date of receipt of the request for reconsideration. The MCO will make a decision regarding the registration of the immovable property right within 15 days from the day of receipt of the request for reconsideration. ${ }^{20}$

When the MCO considers that the Applicant has met the criteria for registration, it will keep a record of such a decision and register the immovable property right accordingly. Within thirty (30) days from the date of receipt of the written decision of the MCO on the refusal to register the right of immovable property, the Applicant may request the KCA to review the decision of the $\mathrm{MCO}^{21}$

The KCA must review the decision of the MCO within 30 days from the day of receipt of the request. The MCO must implement the decision of the AKM. If the MCO does not implement the decision, then the KCA will implement that decision. The aforementioned decision of the AKM will be subject to judicial review in accordance with applicable law.

\section{6. Procesimi dhe regjistrimi}

Upon receipt, the application is registered with KCLIS-T through the Case Registration page. The case receives an automatic number from the system and the correct date is recorded. The type of issue chosen depends on the application (for example: "Merge", "Subdivision", "Sporadic measurement", etc.).

The supervisor assigns the matter to the processing officer who will do the processing and send it to the verifier to verify the results of the process.

The processing officer decides the matter at KCLIS-T based on the documents submitted directly by the applicant or by geometry. Once verified, the issue is considered valid and should be sent for verification.

Prior to verification, Cases requiring a public notification procedure must be included in the list of public notices through the KCLIS-T verification page. ${ }^{22}$

These cases include:

- ownership and possession transaction;

- lease contract over 3 years, lease contract over 10 years and lease contract over 99 years.

The public notice list should be generated, printed (using KCLIS-T), and then displayed in the municipality on the bulletin board for 5 working days. After the expiration of the notice period, the verifier is notified that the Case is ready for decision through the Verification page. ${ }^{23}$

\footnotetext{
${ }^{18}$ Ibid. Article 13, Paragraph 5

${ }^{19}$ Ibid. Article 27, Paragraph 1.

${ }^{20}$ Ibid. Article 27, Paragraph 2.

${ }^{21}$ Ibid. Article 27, Paragraph 1.

${ }^{22}$ ACA / 2011Using User through Business Processes using KCLIS-T, Case Management Module, Part 2.

${ }^{23}$ Ibid.
} 
Other rights, e.g. mortgages, easements, tax liens, etc. They are not the subject of a public announcement and KCLIS does not require the submission of a list of public announcements.

KCLIS allows the verifier to accept or reject the Procedures. If the applicant has not submitted all the necessary documents, or if the case cannot be processed for various reasons, the verifier may also reject the case.

The verifier sets a deadline of 15 days for the applicant to submit complete documentation (see 14.6). If you do not submit them within this deadline, the matter is rejected. Once accepted, the case will be closed and the cadastral records modified during the processing of the case will be permanently stored in the KCLIS-T database.

\section{7. Registration of real estate}

During the process of reconstruction of the Cadastre, the documentation for the formalization of informal transactions that for some reason, until then have remained outside the cadastral system should be requested and reviewed. Registration or changes in KCLIS may be based only on documents provided by entities wishing to register. First, the economic operator must ask the owner / user to submit the legal documents for the registration of property rights. These documents must be accepted from the beginning of the work of the EO until the end of the Public Viewing. ${ }^{24}$ The real estate register is a mechanism, which is administered by state bodies in which all data on real estate are kept. Registration is the act (action) by which are recorded in these special registers, some legal actions related to real estate and aimed at the transfer of any real right related to these properties. ${ }^{25}$ The initial registration of any immovable property is done by preparing a card and an indicative map of the registration in accordance with the provisions of this law and in accordance with the provisions of any act that determines the ownership or agreements or obligations that exist for immovable property. Failure to register a property purchase agreement can put you at great risk. ${ }^{26}$ Any document that is required to be registered but is not registered cannot be admitted as evidence in any court.

There are two main systems for the consequences of registration:

1 - The system that requires registration for the purpose of gaining ownership or other real right. This is called the cadastral system.

2-The system that does not require registration for the purpose of gaining the right, as a cause of preference. This system is called the transcription system; ${ }^{27}$

An example of the latter, which relies on the transcription system is the French system. The cadastral system has been accepted and from the Kosovo system we can clearly distinguish this in the form of legal action, where registration is required as an element for the validity of the legal action and the acquisition of ownership. ${ }^{28}$ The cadastre can be defined as a register, a general inventory of real estate in a given territory, as a set of documents that accompany real estate, whether land or buildings that exist within a state. The cadastre as a concept has evolved and perfected to the form it has today as a register of real estate. In the past it has not only been specified for real estate, but has generally been a form of registration for both movable and immovable property, for keeping a record for the purpose of paying tax. ${ }^{29}$ The tax purpose has been the basis of the cadastre, precisely the need to determine taxable income. The legal purpose today consists in the possibility to provide cadastral documents with legal value, to prove the rights registered in the cadastre through cadastral documents. The administration of the cadastre in the Republic of Kosovo is done by the Kosovo Cadastral Agency in accordance with the provisions of applicable laws. It is the highest authority for Cadastre, Geodesy and Cartography in Kosovo that deals with the maintenance of all official records of immovable properties based on land surveying and cadastre data. Given the difficulties that existed in Kosovo before 1999, the registration of assets today is a challenge as a result of difficulties coming from the past. The non-registration of real estate has occurred for many main reasons, among which: the lack of a complete legal infrastructure, the lack of urban plans and construction plots. There is also a lack of registers in the

\footnotetext{
${ }^{24}$ Shih: http://www.qbz.gov.al/botime/PasuritePaluajtshme.pdf;

${ }^{25}$ Shehu, Avni, Property, Tirana, 2000, p, 100;

${ }^{26}$ See: The Law. No. 7843, dated 13.7.1994, on the registration of immovable property. Article 13, paragraph 1;

${ }^{27}$ See: https://housing.com/news/laws-related-registration-property-transactions-india/;

${ }^{28}$ Such a thing is provided in the Law on Property and Other Real Rights of Kosovo.

${ }^{29}$ See: http://geomatica.como.polimi.it/corsi/catasto/storia.pdf vizituar për herë të fundit më datë 01.06.2017;
} 
ISSN 2661-2666 (Online) International Scientific Journal Monte (ISJM) DOI: 10.33807/monte.20211895

Volume 4, (No).2 (2021): April

municipalities which were obtained during the war. Regarding the realization of the civil purpose of the cadastre, in this period the information is made available through cadastral documents and especially the detailed detailed planimetry of the entire national territory, and the analysis of each parcel of agricultural and urban land. ${ }^{30}$ The basic unit of the cadastre is the land parcel, buildings, parts of the building or conduits. Each municipality is divided into Cadastral Zones. Cadastral Zone means a part of the land area defined geographically, usually a village in rural areas or a city or part of it in urban areas. The cadastre consists of two main parts, the register of real estate data and technical data, which relate to the graphic maps of the basic unit of the cadastre, whether it is a plot of land or a building as part of real estate.

To register immovable property in the cadastral register the main documents that must be submitted are:

- a valid document from a competent body whether judicial or administrative.

- decision of the competent court.

- legal transaction, evidenced by documents in accordance with applicable laws. ${ }^{31}$

Characteristic of the cadastral system today in Kosovo is the digitization of data and the use of the database in addition to the manual books used in the previous system. During a research conducted in two municipalities of the Republic of Kosovo for the purpose of verifying manual and digital cadastral data, it was noticed that there was a discrepancy between the data passed from the manual books to the electronic database. ${ }^{32}$ In the case of the Cadastre, the principle of publicity applies, which means that everyone has the right to receive information - data provided by the Cadastre - except as regulated in paragraph 2 of Article 22 of the Law on Cadastre. ${ }^{33}$

\section{8. 1. Manner of Registration:}

The registrar, a person or any group charged by the registrar requires that the ownership as well as the boundaries of each asset to be registered be documented using the following criteria:

a) Ownership and limits of immovable property are determined by acts of acquisition of ownership, ${ }^{34}$

b) Individuals, families and legal entities, private or state, who own ownership documents, according to letter "a", but do not have defined in them the area of immovable property, have the right to submit to the registrar a request for registration of ownership., which must be accompanied by the ownership document, a plan or master plan of the property, the notary declaration of the neighboring owners, certifying the content of the request for ownership and the boundaries of the claimed property, as well as notarized copies of various documents, which support the application for registration. The registrar, within 30 days from the submission of the request, must return the answer to the applicant after the payment of the expenses, which are prepaid by the applicant. Against the decision of the registrar or in the absence of a response, after this deadline, the applicant may appeal to the court. In litigation the court summons all owners, whose properties are adjacent to each other and who have a legitimate interest in the trial. ${ }^{35}$

So the application for registration of ownership must contain:

- ownership document;

- a property survey plan, prepared by a licensed entity for topographic works, at the request of the interested party or by the Real Estate Registration Office;

- notarized statement of the border owners, certifying the content of the request for the boundaries of the property that is claimed to be registered. The registrar, within 30 days from the date of submission of the request, must return the answer to the applicant, after payment of the costs, which are prepaid by the applicant. Against the decision of the registrar or in the absence of a response, after this deadline, the applicant may appeal to the court. In the court process, the court summons all the owners, whose properties border each other, and who have a legitimate interest in the trial.

c) For the transfer of ownership of the surface, when the ownership document is marked "yard in use", the applicants must address the bodies for restitution and compensation of property. For cases, which are not subject to the law on restitution

\footnotetext{
${ }^{30}$ See: http: //www.delhi.gov.in/wps/wcm/connect/doit_revenue/Revenue/Home/Services/Property+Registration .

${ }^{31}$ See: Law on Cadastre, Article 7 Units in Cadastre;

${ }^{32}$ See: http://www.qbz.gov.al/botime/PasuritePaluajtshme.pdf;

${ }^{33}$ Meha, Murat, Analysis of Cadastral Data in the Perspective of Land Administration in Kosovo;

${ }^{34}$ See: http://www.qbz.gov.al/botime/PasuritePaluajshme.pdf

${ }^{35}$ See: Civil Code of Albania. Article 193;
} 
ISSN 2661-2666 (Online) International Scientific Journal Monte (ISJM) DOI: $10.33807 /$ monte.20211895

Volume 4, (No).2 (2021): April

and compensation of property, applicants turn to the institution authorized by the Council of Ministers. The procedure for the transfer of ownership of this area, in these cases, is determined by a decision of the Council of Ministers. ${ }^{36}$

\section{8. 2. Public announcement}

The temporary registration must be posted for 45 days in a convenient place for public consultation within the geographical area where these assets are located. An announcement will also be made for this 45-day period in a public manner to notify individuals who may make any real estate claims. All errors or allegations must be reported to the registrar at the time of posting. No claim submitted after this 45 day period will be accepted for consideration. ${ }^{37}$ Information on the registration, according to Article 25 of this law, must be posted for 45 days in a place suitable for public consultation, within the cadastral zone where these assets are located. ${ }^{38}$ This posting should also be accompanied by a public announcement to notify individuals who may have a claim to the registered real estate. All errors or allegations made during the posting must be reported to the registrar. Any claim submitted after this 45-day posting period will not be accepted for review by the registrar. At the request of the owner of the immovable property or the lessee, to whom no certificate of ownership or lease has been issued, the registrar shall issue to the owner a certificate of ownership or lease, as the case may be, in writing reflecting all information contained in card of this property and which have effect on the immovable property or on the lease contract. ${ }^{39}$ For each immovable property, registered in the respective card, for ownership, mortgage or for various contracts that have been realized on this property, only one certificate is issued. The certificate of ownership, lease or mortgage is valid evidence for the issues indicated in it, while the real estate lease or mortgage contract is subject to all those that are written on the card both in the case when these are recorded in the certificate and when are not marked. The date of issue of the certificate of ownership, lease or mortgage is recorded on the card.

\section{Conclusion}

Land rights (immovable property) are sometimes also called land interest, because when a 'land transfer' occurs, what actually happens is that the land interest is transferred from one person to another. Land ownership implies a certain interest in land (immovable property). This interest in land may include the right to buy it (in some countries foreigners may not acquire this right, while in some other countries there are special restrictions on border areas) and the right to sell or sell it. rented to someone else. They may include servitudes (such as rights of way and other third party interest), profits (such as the right to take minerals (mines), cut or harvest fruits such as are olives), and restrictions such as mortgages, in which rights are transferred to a third party temporarily in exchange for the loan or the right to sell is transferred in the event that the loan is not repaid on time. They also include exploitation rights, many of which are controlled by physical planning regulations, such as the right to build on land or to perform certain functions such as selling products. In such cases, the lack of right is a restriction, which is in fact a negative right. In some legal systems there is an assumption that if the right is not provided by law, it does not exist; in others, the right exists if it is not removed by laws and regulations. Rights can also be revoked by the owner himself in the form of restraint agreements; eg 'A' sells the land to 'B' with the condition and restriction that ' $\mathrm{B}$ ' does not use the property for a specific purpose, such as raising the building above a certain height to protect (not cover) its appearance 'A' s. Limited (real) property rights (except for some special rights such as the eternal right to live in a certain part of the building) can be sold separately from the main property right. After the death of the owner, the limited rights are transferred to the heirs and 'go with the land', which means, they will continue even if the main property right is sold. ${ }^{40}$

In most countries, the whole set of property rights is not documented. Moreover, the interest in agricultural land is very different from the city and in terms of administration, it is recorded in the land books and cadastral registers and is usually a small subset of the rights which exist in reality. There are many more important interests which have legal force even though they are not registered in land (immovable property) registers, such as traditional rights of way (road) or light.

\footnotetext{
${ }^{36}$ See: Law no. 33/2012. Law on Immovable Property Registration. Article 25;

${ }^{37}$ See: http://www.ikub.al/Ligje/1204200123/Article-PeR-REGJISTRIMIN-E-PASURIVE-Te-

PALUAJTSHME.aspx;

${ }^{38}$ See: http://80.78.70.231/pls/kuv/f?p=201:Ligj:33/2012:21.03.2012;

${ }^{39}$ See: Law no. Nr. 33/2012. // On the registration of immovable property of Albania. Article 32, paragraph 1.

${ }^{40}$ See: Ligjin.Nr.7843, datë 13.7.1994, për regjistrimin e pasurive të paluajtshme. Neni 28;
} 


\section{For the legislature:}

\section{Recommendation}

- The normative framework related to immovable property needs to be channeled and harmonized with local laws and international human rights standards. Property laws must be kept in a minimum number of legal texts and the language must be clear.

- Any new law addressing immovable property should specify by a provision that immovable property may not be transferred without (1) a written contract (2) officially verified and (3) subsequently registered in the cadastre.

- Legislation should directly address the issue of how courts should deal with situations where the parties have not entered into a written contract for real estate transactions because discriminatory legislation in force at the time of the transaction prohibited them from acting in that way. The Supreme Court of Kosovo should instruct the lower courts how to address such cases.

- Evidence rules should be developed which address the admissibility and relevance of evidence. Specific guidance on which parts of the evidence carry more weight than others, e.g. documents issued by a government agency are presumed to be valid and have more weight than the testimony of a witness, which can help address the lack of reasoning in many court decisions. 


\section{Literature}

- Aliu, Abdulla, Property Law (Ownership), Prishtina, 2006;

- Aliu, Abdullah, Property Law, Prishtina, 2009;

- Aliu, Abdullah, Property Law, Prishtina, 2014;

- Dodaj, Marjan, Civil Law (Part II - Property), Prizren / Kosovo (2007/036), / Law on Property and Other Real Rights of the Republic of Macedonia, 2001/2008/2009/2010, Article 112;

- Gashi, Haxhi, Invitation and Loss of Property under the Law on Property and Other Real Rights: The Influence of the German Civil Code on the Law of Kosovo, Magazine "Right", No.2 / 2012;

- Games, Andrea, Basics of Real Law. Prishtina, 1972 (Renaissance);

- Galgano, Francesco, Private Law, Tiran, 2006;

- Krasniqi, Armend, Business Law, Prishtina, 2016;

- Medjedovic, Sefer, "Stvarno Pravo" Novi Pazar, 2011.

- Meha, Murat, Analysis of Cadastral Data in the Perspective of Land Administration in Kosovo;

- Statovci. Ejup. Statovci, Ownership, origin and development, Prishtina 2009;

- Selmani, Union, Roman Law, Macedonia, 2013;

- Shehu, Avni, Property, Tirana, 2000;

\section{Applicable laws}

- The Constitution of the Republic of Kosovo;

- Law no. 03 / L-154. // On Property and Other Real Rights of Kosovo;

- Law no. 2002/5, On the Establishment of the Register of Immovable Property Rights of the Republic of Kosovo;

- Law no. 2003/25 on Kosovo Cadastre;

- Law no. Housing, 1999;

- Law no. 04 / L-077, / on Kosovo Obligations (LMD);

- Law on Property and Other Real Rights of the Republic of Macedonia, 2001/2008/2009/2010;

- Law on Contracted Mortgage of the Republic of Macedonia;

- Civil Civil Code of the Republic of Albania, 1994/1999/2001/2012;

- The law. No. 7843, dated 13.7.1994, on the registration of immovable property in Albania;

- Law no. Nr. 33/2012. // On the registration of immovable property of Albania;

- Civil French Civil Code (French Civil Code - English Translation of 2004;

- AAK / 2011 User Guide through Business Processes using KCLIS-T, Services Module, Part 2;

- AAK / 2014SIKTK Cadastral Mapping Systems, Guidance and Reference Command, Part 2;

- Additional Protocol, Article 1 of the International Resolution on Freedom and Human Rights; 